\title{
SUB-ARBORESCENT LYCOPHYTES IN COAL-BEARING STRATA FROM THE ARTINSKIAN (EARLY PERMIAN/CISURALIAN) OF THE SANTA CATARINA COALFIELD (PARANÁ BASIN, SC, BRAZIL)
}

\author{
JOSELINE MANFROI \\ Setor de Botânica e Paleobotânica, Museu de Ciências Naturais, UNIVATES. Av. Avelino Tallini, 171, \\ 95900-000, Lajeado, RS, Brasil.joselinemanfroi@universo.univates.br \\ ANDRÉ JASPER \\ Programa de Pós-Graduação em Ambiente e Desenvolvimento, UNIVATES, Av. Avelino Tallini, 171, \\ Bairro Universitário, 95900-000 Lajeado RS, Brasil.ajasper@univates.br \\ MARGOT GUERRA-SOMMER \\ Instituto de Geociências, UFRGS, Cx. P.15001, 91509-900, Porto Alegre, RS, Brasil.margot.sommer@ufrgs.br \\ DIETER UHL \\ Institut für Geowissenschaften, Universität Tübingen, Sigwartstraße 10, 72076 Tübingen, Germany. \\ dieter.uhl@senckenberg.de
}

\begin{abstract}
In the modern flora, lycophytes are restricted to a few herbaceous forms. The fossil record of this group is significantly larger, with numerous herbaceous, but also arborescent representatives, the latter mostly reported from late Paleozoic biomes. An association of compressed caulinar fragments of horizontally layered, sub-arborescent lycophytes (preserved as fossil casts) coming from a clastic level which overlies the Bonito coal seam in the Bonito I mine in the Santa Catarina coalfield (Santa Catarina state, Brazil) is analyzed in this paper. The material was identified as Brasilodendron pedroanum (Carruthers) Chaloner, Leistikow \& Hill, a taxon that has been described from several outcrops in the coal-bearing interval of the Paraná Basin (Sakmarian/Artinskian). The present study supports the interpretation that sub-arborescent lycophyte plants showing the Brasilodendron leaf-cushion type were an important component of the coastal peat forming paleofloristic associations during the Early Permian (Cisuralian) in the Paraná Basin and were important contributors to the original biomass of coals.
\end{abstract}

Key words: Paraná Basin, Permian, sub-arborescent lycophytes, Brasilodendron.

RESUMO - A representatividade do grupo das licófitas na flora atual está restrita a poucas formas herbáceas. Este grupo, todavia, possui um vasto registro fóssil, constituído por elementos herbáceos e arborescentes que ocorrem, principalmente, nas associações paleoflorísticas do Neopaleozoico. Formas subarborescentes de licófitas constituíram-se em importantes elementos de biomas tropicais e temperados no Neopaleozoico. No presente trabalho, são descritos fragmentos caulinares de licófitas subarborescentes (moldes e contramoldes) provenientes de nível clástico suprajacente à camada de carvão da mina Bonito I (Lauro Müller/SC) aflorante nas imediações da mina. O material foi identificado como pertencente a Brasilodendron pedroanum (Carruthers) Chaloner, Leistikow \& Hill, espécie já registrada em diferentes afloramentos no intervalo de deposição de carvão da bacia do Paraná (Sakmariano/Artinskiano). Fica confirmado, dessa forma, que licófitas sub-arborescentes foram o componente relevante das associações paleoflorísticas relacionadas a turfeiras desenvolvidas em ambientes costeiros durante o Eopermiano (Cisuraliano) na bacia do Paraná.

Palavras-chave: bacia do Paraná, Permiano, licófitas subarborescentes, Brasilodendron.

\section{INTRODUCTION}

According to Gensel \& Berry (2011) lycophytes are vascular cryptogamic plants characterized by monopodial growth or dichotomical branching, densely covered by helically arranged microphylls which are vascularized by a vein without interruption from the caulinar stele.

Currently lycophytes are represented mainly by herbaceous forms and restricted to three families (Lycopodiaceae, Selaginellaceae and Isoetaceae), four broad genera (Selaginella 
Palisot de Beauvois, 1805, Lycopodium Linnaeus, 1753 sometimes divided into four or more genera, Phylloglossum Kunze, 1843 and Isoetes Linnaeus, 1753) and about 1.250 species, and belong to the order Lycopodiales (Judd et al., 2002). They have a large geographical distribution and can be found on almost all continents (Wagner \& Beitel, 1992; Ollgaard, 1992).

Despite their relatively low diversity in the modern flora, the lycophytes have a large fossil record, with a peak diversity of arborescent forms during the Permo-Carboniferous in different paleogeographic provinces (Taylor et al., 2009). However, at the Permian/Triassic boundary the diversity of arborescent forms strongly declined and only a few larger forms like Pleuromeia Corda, 1852 and Nathorstiana Karrfalt, 1984; occurred during the Mesozoic (e.g. Taylor et al., 2009). According to DiMichele (1985), the arborescent lycophytes constituted up to $70 \%$ of the biomass responsible for the formation of the Bashkirian and Moscovian coal levels from Euramerica. At the end of the Moscovian and during the Kazimovian and Gzhelian the diversity and abundance of arborescent lycophytes declined to 5\% (Kerp, 2000) and during the Early Permian (Asselian - Sakmarian) arborescent lycophytes (i.e. belonging to the single species Sigillaria brardii Brongniart, 1828) were rather rare elements of the Euramerican palaeoflora (e.g. Schindler et al., 2004). Despite this drop in Euramerica, the group persisted in other regions as an important part of floras until the Late Permian (Lopingian) (e.g. Wang \& Chen, 2001).

Several types of arborescent lycophytes are known from Gondwana and these are mostly associated with coal-bearing strata, which developed during the Permian. Genera like Aspidaria (Pseudobumbudendron) Paint \& Srivasttava, 1995, Bumbudendron Archangelsky, Azcuy \& Wagner, 1981 and Brasilodendron (Carruthers) Chaloner, Leistikow \& Hill, 1979 are considered to represent important cormophytic elements in many paleofloristic associations from Gondwana and have so far been observed in a large number of localities (Paint \& Srivastava, 1995; Archangelsky et al., 1981; Chaloner et al., 1979).

In the Permian of the Paraná Basin, herbaceous [e.g. Lycopodites (Salvi et al., 2008)], shrubby [e.g. Lycopodiopsis (Renault, 1890)] and (sub)arborescent [e.g. Brasilodendron (Chaloner et al., 1979)] forms have been described, sometimes as elements of canopy and also as understory forms within a single roof shale flora (Jasper et al., 2006).

Despite the abundance of fossil plants reported for the Santa Catarina Coalfield, formal descriptions have been restricted to the Irapuá coal seam (Bernardes-de-Oliveira, 1969, 1977, 1980). The present study has the main goal of establishing the taxonomic affinities for a compressed lycophyte cast association, dispersed in a clastic level overlying the Bonito coal seam. This will allow ratification of the importance of these plants in the coal forming floras during almost all the Early Permian in the Paraná Basin.

\section{GEOLOGIC AND STRATIGRAPHIC BACKGROUND}

According to Milani (2003), the Paraná Basin can be interpreted as an intracratonic basin with an area of approximately 1,400,000 $\mathrm{km}^{2}$, covering parts of southern Brazil, Paraguay, Uruguay and Argentina. Basin floor subsidence and Paleozoic sea-level changes created a six second-order sequences system, deposited from the Ordovician up to the Late Cretaceous, and separated by regional unconformities. The coal-bearing Rio Bonito Formation is included in the Gondwana I Supersequence (Carboniferous/Early Triassic).

Sedimentological, petrographic and stratigraphic studies have demonstrated that peat deposits occurred adjacent to paralic, estuarine, deltaic, backshore and shoreface siliciclastic deposits in back-barrier coastal swamp environments (Alves \& Ade, 1996; Holz, 1998; Holz et al., 2002).

The Rio Bonito lithostratigraphic unit was subdivided by Schneider et al. (1974) into three major packages with a hierarchy of members labeled from the base to top: Triunfo (coastal and fluvial sandstones), Paraguaçu (marine mudstones and fine-grained sandstones) and Siderópolis (coastal and fluviatile sandstones).

The Santa Catarina coalfield (Artinskian) is located in a polygon of approximately $1,200 \mathrm{~km}^{2}$ in the southeastern portion of the Santa Catarina State. From top to base, the coal seams included in the Siderópolis Member are: Barro Branco, Irapuá, "A", "B", Ponte Alta, Bonito and the minor coal layers Pre-Bonito " $C$ " and " $D$ ".

The Bonito I mine, near the municipality of Lauro Müller, exploits the so-called Bonito coal seam, which has a thickness of approximately $2.0 \mathrm{~m}$ in this area. Together with the Barro Branco coal seam, the Bonito coal seam constitutes the most important coal reserve in the Santa Catarina State.

\section{MATERIAL AND METHODS}

The studied material comes from a light gray silty layer, which overlies the Bonito coal seam at the Bonito I mine [Lauro Müller municipality, Santa Catarina State, Brazil (Figure 1)].

A total amount of 15 fragments (impression-compressions) of stems belonging to lycophytes that were horizontally layered, dispersed, without orientation, were collected from a clastic level, overlying the coal seam at the Bonito I mine region, and subsequently catalogued in the collection of the Setor de Botânica e Paleobotânica do Museu de Ciências Naturais, UNIVATES under the acronym PbU.

The morphology of the samples was investigated using a Leica MS 5 stereomicroscope. Morphological details were photographed using this equipment and a camera lucida for drawings. Measurements were taken using a standard ruler for the larger dimensions (e.g. size of complete fragments) and a 6"/ $150 \mathrm{~mm}$ Stainless Hardened Electronic Digital Caliper, for smaller details (e.g. leaf cushions). 


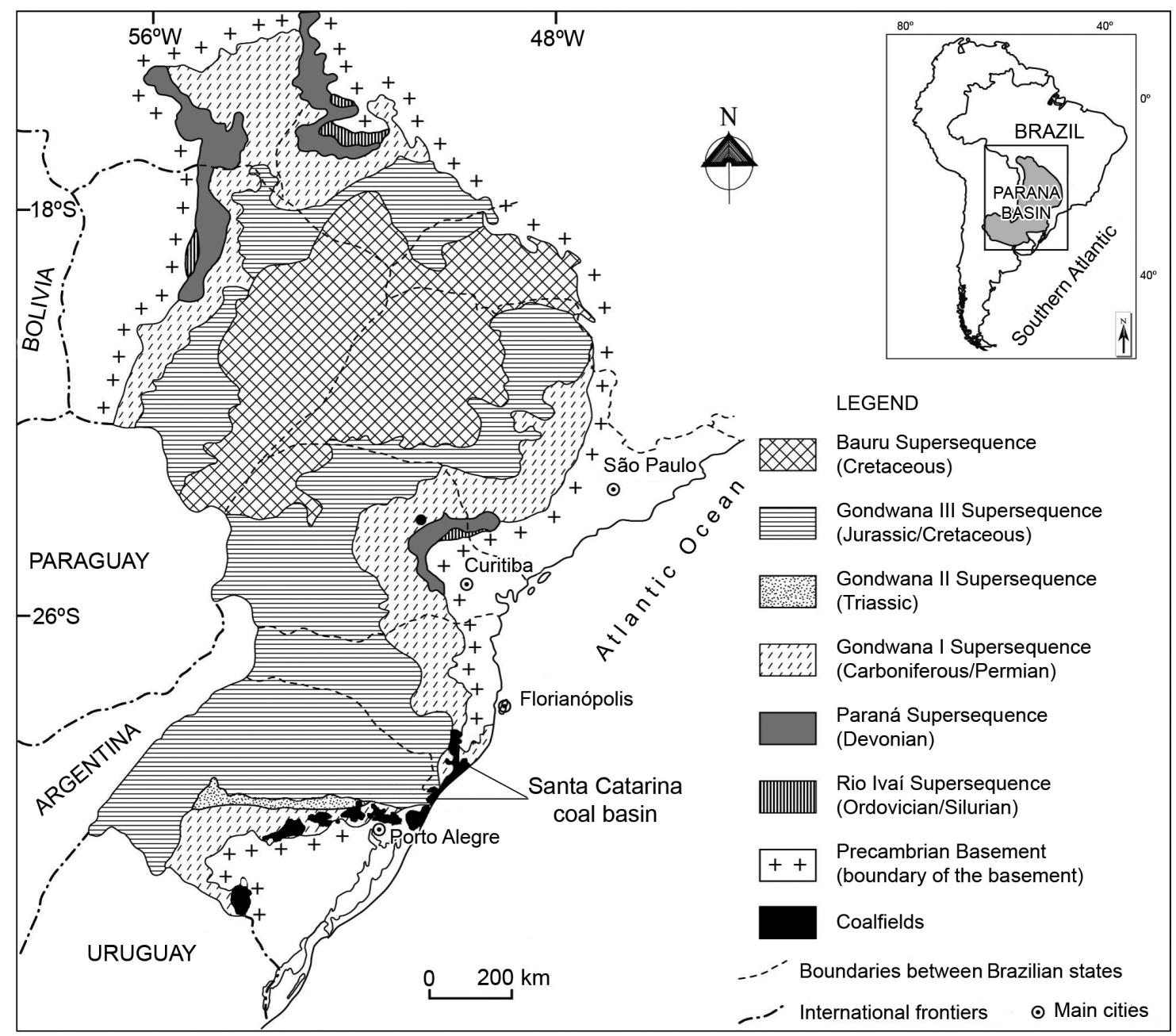

Figure 1. Simplified geological map of the Paraná Basin in Brazil with major tectonic elements and geographic positions of the studied locality with indication of the Santa Catarina Coal Basin (modified from Jasper et al., 2011).

Macroscopic charcoal fragments were extracted mechanically from two samples (PbU 790 and 791), with the aid of preparation needles and tweezers under a binocular microscope. Due to the very fragile nature of the specimens, they could not be cleaned with water or any acids to remove adhering mineral remains. The fragments were mounted on standard stubs with LeitC (Plano GmbH, www.planoem.de) and examined with the aid of a Scanning Electron Microscope (SEM) JEOL JSM 6360 at the Technology Centre of Universidade Federal de Santa Maria.

Taxonomical affinities were established using the identification key published by Thomas \& Meyen (1984) as well as other publications (Jasper \& Guerra-Sommer, 1998, 1999), which complement the systematics of sub-arborescent lycophytes from Gondwana.

\section{RESULTS AND DISCUSSION}

The material is composed of caulinar impressioncompressions belonging to sub-arborescent lycophytes, which were submitted to a three-dimensional fossilization. The surface of the stems is slightly decorticated, but the leaf cushions are well preserved. Fossil charcoal, cited before by Jasper et al. (2011), was observed at the surface of some fragments (Figure 2), reinforcing that the lycophytes had been affected by wildfires, which occurred in the area.

The stems are 42.0 to $147.0 \mathrm{~mm}$ long, 21.0 to 130.0 $\mathrm{mm}$ wide and 8.0 to $138.0 \mathrm{~mm}$ thick. The leaf cushions are helically arranged (lepidodendroid phyllotaxis) and no ligule or parichnos or vascular-bundle scar could be observed (Figure $3 \mathrm{~A})$. The leaf cushions are fusiform, without extensions at the top or at the bottom, and are 5.6 to $8.7 \mathrm{~mm}$ high and 4.1 to $6.7 \mathrm{~mm}$ wide at the middle portion. Poorly preserved rhombic leaf scars, with 1,0 to $2.0 \mathrm{~mm}$ in length and 2.0 to $3.0 \mathrm{~mm}$ in width, are present above the midpoint of some leaf cushions (Figures 3B, 4). The presence of leaves in organic connection with the leaf cushions or evidence of leaf abscission was not observed in any specimen.

Despite the absence of anatomical features, taxonomical affinities can be established with other sub-arborescent lycophytes morphogenera from Gondwana, which had been described based on morphological characteristics (e.g. Renault, 1890; Meyen, 1978; Archangelsky et al., 1981; Chaloner et al., 1979; Paint \& Srivastava, 1995). According to Taylor et al. (2009), the lepidodendroid phyllotaxis and the absence of a ligule, parichnos or vascular-bundle scars, are common 

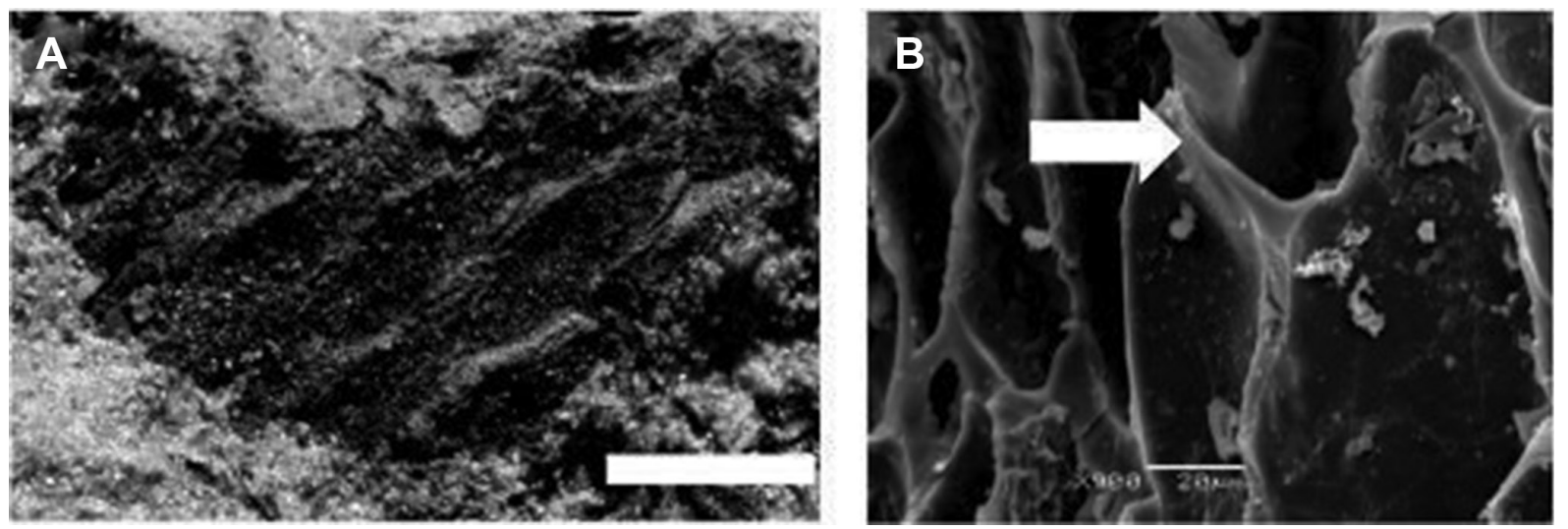

Figure 2. Caulinar impression-compression with paleowildfire evidences (PbU 790): A, detail of the leaf cushions with macroscopic charcoal adhered; B, SEM images of macroscopic charcoal collected from the sample and showing parenchyma with cell walls homogenization (arrow). Scale bar: $\mathrm{A}=7 \mathrm{~mm}$.
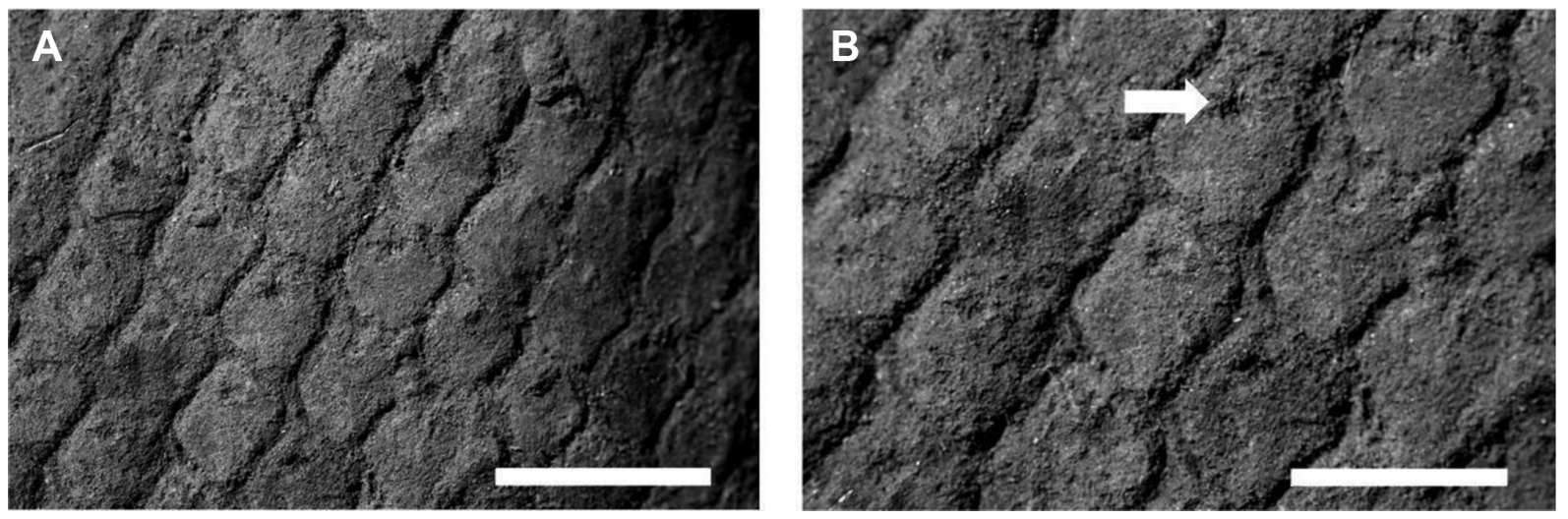

Figure 3. Surface of a studied caulinar impression-compression (PbU 766): A, detail of the leaf cushions lepidodendroid phyllotaxis. B, detail of the leaf cushions with leaf scars (arrow). Scale bars: $A=15 \mathrm{~mm} ; B=7 \mathrm{~mm}$.

to all the genera from Gondwana (Pseudobumbudendron, Bumbudendron and Brasilodendron). Because of this fact the present study also includes this group of taxa into Lycopodiales and not into Lepidodendrales like other subarborescent lycophytes from the northern hemisphere.

Although there are only a few morphological details visible in our material it is possible to infer a taxonomic relation of this material based on the form of the leaf cushions. Fusiform leaf cushions can be considered defining Brasilodendron, the material here described is therefore associated to this genus.

The absence of sigmoidal extensions at the top or at the bottom of the fusiform leaf cushions, which are referred in the original description of Brasilodendron pedroanum (Carruthers) Chaloner, Leistikow \& Hill, 1979, is also a common characteristic in basal portions of the lycophyte stems described by Jasper \& Guerra-Sommer (1998, 1999). This demonstrates some morphological variability, which can probably be explained by intra-specific, positional variability, due to variations in the ontogeny of individual plants.

It has to be considered that these characteristics are also consistent with the Euroamerican genus Ulodendron (Lindley \& Hutton) Thomas (1967), although this taxon clearly possesses a ligule pit (Thomas, 1967, 1970). This feature and the paleogeographic distribution support the validity of Brasilodendron as a separate genus (Chaloner et al., 1979).

So far only a single species Brasilodendron pedroanum has been assigned to this genus. As there are no distinctive characteristics visible in the present material that would necessitate the erection of a new species, it can formally classify the material as Brasilodendron pedroanum.

The lycophytes are considered bad paleoecological indicators because different taxa may be well adapted to different habitats (DiMichele et al., 2004). Some authors (Walter, 1985; Ziegler, 1990; Pfefferkorn, 1997; Iannuzzi \& Rösler, 2000; Iannuzzi \& Pfefferkorn, 2002) used the sub-arborescent lycophyte forms to delimitate paleoclimatic parameters for Gondwana, considering these plants as indicators of warm temperature climatic belt during the Early Carboniferous (Mississippian). Nevertheless, Balserio et al. (2009) included plant associations from the Early Carboniferous of Southern Patagonia, at high latitude, in the so-called Paracas Realm, as designated by Iannuzzi \& Pfefferkorn (2002). Balserio et al. (2009) greatly amplified the latitudinal extension of this Realm and allowed to conclude that the very close relationship of sub-arborescent lycophytes with Early Carboniferous South American low latitude warm floras needs to be revised. 


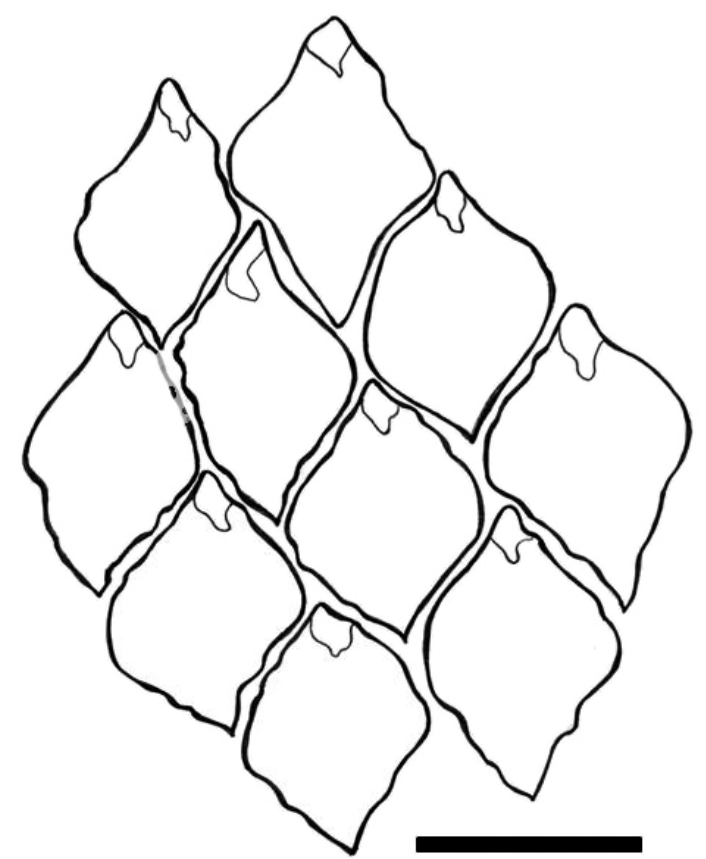

Figure 4. Camera lucida drawing of a caulinar impression-compression surface (PbU 769) with the presence of leaf cushions and leaf scars. Scale bar $=10 \mathrm{~mm}$.

Lycophytes of the Brasilodendron-type have been considered as indicators for the paleoclimatic evolution in Brazilian Gondwana during the Early Permian (GuerraSommer et al., 1995). Recent palynological data link Lundbladispora spores, abundant in Brazilian coals, to subarborescent lycophytes (Cazzulo-Klepzig et al., 2002), and this taxon is probably related to Brasilodendron pedroanum, a common plant in the swampy, coastal environments during the peat deposition interval in southern Paraná Basin, as indicated by roof shale analyses (Jasper et al., 2006). These evidences seems to ratify the hypothesis of GuerraSommer et al. (1995) that the sub-arborescent lycophytes of Brasilodendron pedroanum type reached their climax during the deposition of the coal-bearing strata of the Rio Bonito Formation in Paraná Basin, at the waning of an icehouse stage. Moreover, studies which use sub-arborescent lycophytes as paleoecological indicators are rare for Gondwana, restraining this approach in the present study.

\section{FINAL REMARKS}

Based on the presented data is possible to conclude that the studied samples belong to Brasilodendron pedroanum; the sub-arborescent lycophytes were components of lowland paleofloristic associations, which were influenced by wildfires as demonstrated in previous studies and Brasilodendron pedroanum was an important component of the lowland plant associations of the peat deposition interval, along the Sakmarian-Artinskian interval of the Paraná Basin, and it can be inferred that these sub-arborescent lycophytes have contributed to the original coal biomass of South Brazilian coals.

\section{ACKNOWLEDGEMENTS}

The authors thank A. de Paris, Universidade Federal de Santa Maria, for technical assistance with the SEM facilities; and also thank the important contributions given by G. Ottone and B. Thomas during the revision of this paper. J. Manfroi, A. Jasper and M. Guerra-Sommer acknowledge financial support by FAPERGS and CNPq.

\section{REFERENCES}

Alves, R.G. \& Ade, V.B. 1996. Sequence stratigraphy and coal petrography applied to the Candiota Coal Field, Rio Grande do Sul, Brazil: a depositional model. Coal Geology, 30:231-248. doi:10.1016/0166-5162(95)00041-0

Archangelsky, S.; Azcuy, C.L. \& Wagner, R.H. 1981. Three dwarf Lycophytes from the Carboniferous of Argentina. Scripta Geologica, 64:1-35.

Balseiro, D.; Ruston, J.J.; Ezpeleta, M. \& Vaccari, N.E. 2009. A new Serpukhovian (Mississippian) fossil flora from western Argentina: paleoclimatic, paleobiogeographic and stratigraphic implications. Palaeogeography, Palaeoclimatology, Palaeoecology, 280:517-531. doi:10.1016/j.palaeo.2009.07.005

Bernardes-De-Oliveira, M.E.C. 1969. Flora da Formação Rio Bonito: Glossopteris, Noeggerathiopsis, Sphenopteris, Gangamopteris e Rhabdotaenia na subida do Bainha, Criciúma, Santa Catarina. Programa de Pós-Graduação em Geologia, Universidade de São Paulo, M.Sc. dissertation, 48 p.

Bernardes-De-Oliveira, M.E.C. 1977. Tafoflora Eogondvânica da camada Irapuá, Formação Rio Bonito (Grupo Tubarão), SC. Programa de Pós-Graduação em Geologia, Universidade de São Paulo, Ph.D. thesis, 301 p.

Bernardes-De-Oliveira, M.E.C. 1980. Tafoflora Eogondvânica da Formação Rio Bonito (Camada Irapuá), Bacia do Paraná, Brasil. In: CONGRESO ARGENTINO DE PALEONTOLOGÍA Y BIOESTRATIGRAFIA, 2/ CONGRESO LATINOAMERICANO DE PALEONTOLOGÍA, 1, 1980. Actas, Buenos Aires, 6:69-88.

Cazzulo-Klepzig, M.; Guerra-Sommer, M.; Formoso, N.L. \& Calarge, L.M. 2002. Geochemical and palynological evidence for the age determination of Permian coals, southern Brazil. Journal of South American Earth Sciences, 15:375-380. doi:10.1016/ S0895-9811(02)00042-1

Chaloner, W.G.; Leistikow, K.U. \& Hill, A. 1979. Brasilodendrom gen. nov. and B. pedroanum (Carruthers) comb. nov., a Permiam Lycopod from Brazil. Review of Palaeobotany and Palynology, 28:117-136. doi:10.1016/0034-6667(79)90004-6

DiMichele, W.A. 1985. Diaphorodendron, gen. nov., a segregate from Lepidodendron (Pennsylvanian age). Systematic Botany 10:453-458.

DiMichele, W.A.; Hook, R.W.; Nelson, W.J. \& Chaney, D.S. 2004. An unusual Middle Permian flora from the Blaine Formation (Pease River Group: Leonardian-Guadalupian Series) of King County, West Texas. Journal of Paleontology, 78:765-782. doi:10.1666/0022-3360(2004)078<0765:AUMPFF>2.0.CO;2

Gensel, P.G. \& Berry, C.M. 2001. Early Lycophyte evolution. American Fern Journal, 91:74-98. doi:10.1640/00028444(2001)091 [0074:ELE]2.0.CO;2

Guerra-Sommer, M.; Cazzulo-Klepzig, M. \& Marques-Toigo, M. 1995. Paleoclimatic implications of Lycophyta in the Gondwana of Southern Brazil. Pesquisas, 22:21-31. 
Holz, M. 1998. The Eo-Permian coal seams of the Paraná Basin in southernmost Brazil: an analysis of the depositional conditions using sequence stratigraphy concepts. International Journal of Coal Geology, 36:141-163. doi:10.1016/S01665162(97)00019-0

Holz, M.; Kalkreuth, W. \& Banerjee, L. 2002. Sequence stratigraphy of paralic coal, bearing strata: an overview. International Journal of Coal Geology, 48:147-179. doi:10.1016/S01665162(01)00056-8

Iannuzzi, R. \& Pfefferkorn, H.W. 2002. A pre-glacial, warmtemperate floral belt in Gondwana (Late Visean, Early Carboniferous). Palaios, 17:571-590. doi:10.1669/08831351(2002)017<0571:APGWTF>2.0.CO;2

Iannuzzi, R. \& Rösler, O. 2000. Floristic migration in South America during the Carboniferous: phytogeographic and biostratigraphic implications. Palaeogeography, Palaeoclimatology, Palaeoecology, 161:71-94. doi:10.1016/ S0031-0182(00)00118-8

Jasper, A. \& Guerra-Sommer, M. 1998. Licófitas cormofíticas arborescentes do Afloramento Quitéria - Formação Rio Bonito (Bacia do Paraná), RS. Pesquisas, 25:43-60.

Jasper, A. \& Guerra-Sommer, M. 1999. Licófitas arborecentes in situ como elementos importantes na definição de modelos deposicionais (Formação Rio Bonito - Bacia do Paraná - Brasil). Pesquisas, 26:49-58.

Jasper, A.; Menegat, R.; Guerra-Sommer, M.; Cazzulo-Klepzig, M. \& Souza, P.A. 2006. Depositional cyclicity and paleoecological variability in Quitéria Outcrop - Rio Bonito Formation, Paraná Basin, Brazil. Journal of South American Earth Sciences, 21:276-293. doi:10.1016/j.jsames.2006.05.002

Jasper, A.; Uhl, D.; Guerra-Sommer, M.; Bernardes-de-Oliveira, M.E.C. \& Machado, N.T.G. 2011. Upper Paleozoic charcoal remains from South America: multiple evidences of fire events in the coal bearing strata of the Paraná Basin, Brazil. Palaeogeography, Palaeoclimatology, Palaeoecology, 306:205218. doi:10.1016/j.palaeo.2011.04.022

Judd, W.S.; Campell, C.S.; Kellogg, E.A. \& Stevens, P.F. 2002. Plant Systematics: a phylogenetic approach. Massachussets, Sinauer Associaties Inc. Publishers, $464 \mathrm{p}$.

Kerp, H. 2000. The modernization of landscapes during the Late Paleozoic-Early Mesozoic. Palaeontological Society Papers, 6:79-113.

Meyen, S.V. 1978. Systematics, phylogeny and ecology of Propteridophytes. Bulletin of Moscow Society Naturalists, Section Biology, 83:72-84.

Milani, E.J. 2003. Estratigrafia da Bacia do Paraná - algumas considerações metodológicas. In: ENCONTRO SOBRE ESTRATIGRAFIA DO RIO GRANDE DO SUL: ESCUDO E BACIAS, 2003. Anais, Porto Alegre, UFRGS, p.18-22.

Ollgaard, B. 1992. Neotropical Lycopodiaceae - an overview. Annals of the Missouri Botanical Garden, 79:687-717.

Paint, D.D. \& Srivasttava, P.C. 1995. Lower Gondwana insect remains and evidence of insect-plant interaction. In: INTERNATIONAL CONFERENCE OF GLOBAL ENVIRONMENT AND DIVERSIFICATION OF PLANTS THROUGH GEOLOGICAL TIME, 1995. Proceedings, Allahabad, 317-326.

Pfefferkorn, H.W. 1997. Paleoclimates of Perú during the late Paleozoic - fossil plants and morring continents. Sociedad Geológica del Perú, p. 671-673.

Renault, B. 1890. Sur une nouvelle Lycopodiaceae (Lycopodiopsis derbyi). Comptes Rendus de l'Académie des Sciences de Paris, 100:809-811.

Salvi, J.; Jasper, A.; Ricardo-Branco, F.; Bernades-De-Oliveira, M.E.C. \& Guerra-Sommer, M. 2008. Record of the genus Lycopodites in the Lower Permian of Paraná Basin, Brazil. Anais da Academia Brasileira de Ciências, 80:553-563. doi:10.1590/ S0001-37652008000300015

Schindler, T.; Uhl, D.; Noll, R.; Poschmann, M.; Bach, T.; Höhn, W.; Rahm, B.; Schweiss, D. \& Wuttke, M. 2004. Erstfunde von Sigillaria-Stämmen in situ in Rotliegend-Ablagerungen (OberKarbon bis Unter-Perm) der Nordpfalz (Südwestdeutschland). Neues Jahrbuch für Geologie und Paläontologie, Abhandlungen, 233:1-26.

Schneider, R.L.; Mühlmann, H.; Tommasi, E.; Medeiros, R.A.; Daemon, R.F. \& Nogueira, A.A. 1974. Revisão Estratigráfica da Bacia do Paraná. In: CONGRESSO BRASILEIRO DE GEOLOGIA, 28, 1974. Anais, Porto Alegre, SBG, 1:41-65.

Taylor, T.N.; Taylor, E.L. \& Krings, M. 2009. Paleobotany: the biology and evolution of fossil plants. $2^{\mathrm{a}}$ ed. Burlington, Academic Press, 1230 p.

Thomas, B.A. \& Meyen, S. 1984. A system of form-genera for the Upper Palaeozoic Lepidophyte stems represented by compression-impression material. Review of Palaeobotany and Palynology, 41:273-281. doi:10.1016/0034-6667(84)90049-6

Thomas, B.A. 1967. Ulodendron Lindley and Hutton and its cuticle. Annals of Botany, 31:775-782.

Thomas, B.A. 1970. Epidermal studies in the interpretation of Lepidodendron species. Palaeontology, 13:145-173.

Wagner, H.W. \& Beitel, J.M. 1992. Generic classification of modern North American Lycopodiaceae. Annals of the Missouri Botanical Garden, 79:676-686.

Walter, H. 1985. Vegetation of the Earth and ecological systems of the geo-biosphere. New York, Springer-Verlag, 274 p.

Wang, Z.Q. \& Chen, N.S. 2001. Traces of arborescent lycopsids and dieback of the forest vegetation in relation to the terminal Permian mass extinction in north China. Review of Palaeobotany and Palynology, 117:217-243. doi:10.1016/ S0034-6667(01)00094-X

Ziegler, A.M. 1990. Phytogeographic patterns and continental configurations during the Permian Period. Memoirs of the Geological Society of London, 12:363-379. doi:10.1144/GSL. MEM.1990.012.01.35

Received in August, 2011; accepted in March, 2012. 